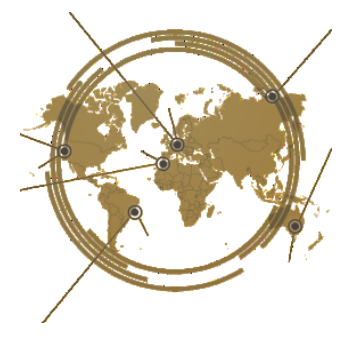

\title{
Reading and its relationships among attitude, motivation, and comprehension achievement in upper secondary school students
}

\author{
Fatimah Tisa, Sofendi Sofendi*, Eryansyah Eryansyah \\ Faculty of Teacher Training and Education, Sriwijaya University, Indonesia
}

Reading is essential in every subject. Reading also has a relationship with the students' achievement. This study is aimed to investigate whether or not there is (1) a significant correlation between reading attitude and reading comprehension achievement, (2) a significant correlation between reading motivation and reading comprehension achievement, (3) a significant correlation between reading attitude and reading motivation, and (4) any correlation between predictor variables and the criterion variable. The study was a correlational study with Pearson-product moment correlation. The sample of this study were 95 eleventh graders of upper secondary school. Cluster random sampling technique is used in this study. Questionnaires of reading attitude, reading motivation, and reading comprehension tests are given. The questionnaire result reveals that the reading attitude was negative, and reading motivation is medium. Furthermore, the results show that reading attitude and reading comprehension has a significant correlation. Reading motivation and reading comprehension also has a significant correlation. The roles of students, parents and teachers must work suitably in order to construct the positive reading atmosphere, thus they could achieve the better achievement in reading even for all subjects.

Keywords: correlation, reading attitude, reading motivation, reading comprehension achievement

OPEN ACCESS

ISSN 2503 3492(online)

${ }^{*}$ Correspondence: fatimahtisa@yahoo.com

Received: $3^{\text {th }}$ August 2020 Accepted: $26^{\text {th }}$ December 2020 Published: 30th March 2021

Citation:

Tisa, F., Sofendi, S., Eryansyah, E. (2021) Reading and its relationships

among attitude, motivation, and

comprehension achievement in

upper secondary school students.

J. Eng. Educ. Society. 6:1.

doi:10.21070/jees.v6i1.751

\section{INTRODUCTION}

Four skills of English must be achieved by students, such as speaking, listening, reading, and writing. Reading is one of the keys that improve learning outcomes in many fields of study. Without reading, nothing can be done to develop competence in listening, speaking, writing, and translating. According to $\mathrm{Li}$ and Wilhelm (2008), language learners need reading since it is one of the most critical skills to help them have other language skills. It is also supported by Hamra and Syatriana (2010) that English cannot be separated from reading. Reading also has the relationship with students' achievement. Reading is a way to know the world because from reading, the reader can have a lot of information and build good communicative competence (Amalia, et. al., 2018).

Reading attitude is one aspect of self-perception of reading ability. The attitude of reading as a part of the self-processing system will support the achievement of reading skills through a combination process with other factors that determine failure or success in student learning. Attitudes towards reading have a direct relationship with reading ability, whereby having a positive reading attitude; students will intensely carry out reading activities and will improve reading skills and reading comprehension skills. 
A positive attitude towards reading supports the development of reading skills and the development of skills related to reading maximally. Negative attitudes towards reading impact the development of reading skills and the less maximal development of skills related to reading.

A person who has an attitude in reading is likely to tend to notice and do things selectively. It can be meant that attitude and self-concept are two things that have an excellent contribution to be had by a person to pursue success or failure in academic achievement. Reading attitude is a system of feelings related to reading which causes the learner to approach or avoid a reading situation (Tunnel, Carder, \&Phaub, 1991).Gorard, Seeand Davies (2011) state that attitude can reflect individuals about education or academic performance.Tunnel, Carder, and Phaub (1991) define reading attitude as a feeling toward reading that causes individuals to fond of or dislikes the reading activity. According to Matthewson (2004), Reading attitude is classified into three aspects, such as towards an object, evaluation of the object, which is in a positive or negative to an object. Walberg and Tsai (1995) mention some factors contributed to a positive attitude. The factors are: (1) believing that reading is important, (2) enjoying reading, (3) having a high self-concept as a reader, and (4) having a verbally stimulating home environment where verbal interaction takes place regularly.

Some factors relate to students' vital role in reading; one of them is motivation. Motivation influences and plays an essential role in learning and reading activity. Because motivation is a primary key for people to do something, as believed by Guthrie, Wigfield, and You (2012), motivation is a reading domain that can help the reader to set goals, build interest and value themselves. Cambria and Guthrie $(2010$, p. 25$)$ state that reading motivation is described as student's enjoyments, their wants and their behaviors surrounding reading. Furthermore, According to Barbara (2012), reading motivation means enjoying a book, being excited about an author or being delighted by new information. Yumei (2009) believes that motivation that students have has been accepted to influence a key factor of success in learning a second of a foreign language. Grabe and Stoller (2002) state that students must have reading motivation since it can increase their reading comprehension. Motivation makes someone willing to read a book and wants to participate in all activities. Reading material is also one of variable influencing individuals to read an English book (Tabaoada\&McElvany, 2009). Chun (2009, p. 147) explains that providing interesting texts is essential in motivating students to read in English. He also adds that student needs to be exposed to interesting and appealing texts from various genres that are appropriate for students' reading level.

Reading comprehension is one of the pillars of the act of reading. Brummit (2008) defines reading comprehension as a critical component of functional literacy. With the ability to comprehend what they read, people cannot only live safely and productively, also continuing to develop socially, emotionally, and intellectually. Reading needs comprehension. Reading Comprehension is understanding, evaluating, and utilizing information and ideas gained through interaction between reader and author (Allan \& Smith, 1990).

Moreover, according to Royer (2004), reading comprehension is the process of understanding and constructing meaning from a piece of text. He also believes that reading comprehension may be affected by the text's difficulty, the vocabulary used in the text, and the readers' familiarity with the subject matter. Generally, to see whether someone understands the meaning of the text, they should do a reading comprehension test. So, it can be considered to understand the text if they can answer most of the questions about it. Reading comprehension is a significant element in language learning because it provides the foundation for a substantial amount of learning in EFL learning (Ahmadi \&PourhoseinGilakjani, 2012). According to Heilman (2002), reading is a process of making sense of written ideas through meaningful interpretation interaction with language.

Some previous studies are related to this study. First, a study was done by Rojak (2018), the research was a case study and. The result showed $69 \%$ of participants who experienced reading program for a month was giving a positive attitude. Second, a study done by Marsela (2017).The study was conducted in Palembang, Indonesia. The result showed that students' motivation has moderate effects on reading comprehension. It means that other factors influence students' reading comprehension achievement besides motivation such as intelligence, attitude, interest, language-learning strategies, etc. A study done by Moriyanti (2015).The result showed that students' reading motivation and their reading achievement showed that the effect of reading motivation was $72.25 \%$ toward their reading achievement, indicating a positive correlation. Last, a study was done by Rizqiyah (2016). The result showed that there was no correlation between reading attitude and reading achievement. However, there was a correlation between two kinds of reading attitude's aspects and reading achievement.

Furthermore, the previous studies above have similarities and differences with this study. It is similar because they used the same variables: readability level, reading motivation, and reading comprehension achievement. However, some gaps between this study and other related studies are shown clearly. Not only have different number of participants but also the difference level of education. This study involved high school students in the research however some previous studies involved higher education students. The location also stated that this study have done in Palembang, Indonesia, while other studies were done outside of Palembang or overseas. There could be a concern that the findings of this study might be transferred to other teachers and the next researchers will be able to examine and scope out the appropriate methodologies to improve the students' reading comprehension achievement and identify the other correlated variables that affect the students' reading comprehension achievement.

The writer is interested in doing research about reading attitude, reading motivation, and reading comprehension achievement of eleventh graders to find out the reading attitude, reading motivation of the students. 
Based on the writer's observation during teaching, it was found that students faced difficulties in reading comprehension. It was hard for them to understand the content of the text, and students were bored (unmotivated) in the teaching and learning process. Some students just read the text without trying to connect the text's presented ideas with their thinking patterns. They only focus on some questions presents in the text without comprehending the text overall-all in all, the reading skill of eleventh graders needed to be developed.

This study has objectives, which were to investigate whether or not: (1) there is a correlation between reading attitude and reading comprehension of the eleventh graders, and (2) To find out whether or not there is a significant correlation between reading motivation and reading comprehension of the eleventh graders, (3) To find out whether or not there is a significant correlation between reading attitude and reading motivation of the eleventh graders, (4) To find out whether or not there is any significant correlation between predictor variables (reading attitude and reading motivation) and a criterion variable (reading comprehension).

\section{METHODS}

This study used the correlational study to determine the correlations among the students' reading attitude, reading motivation, and reading comprehension achievement. Reading attitude and reading motivation as the predictor variable and reading comprehension achievement as the criterion variable. According to McMillan and Schumacher (2010), the variable which influences or predicts is called the independent (predictor) variable, while the one that is affected by or is predicted by the independent variable is the dependent variable (criterion).

A cluster random sampling technique was used to choose the sample class. Fraenkel, Wallen, and Hyun (2012) explain that random cluster sampling is a selection of sample based on groups or cluster subjects. The total population in this study was 204 students and consisted of two classes, science and social. The sample was taken by selecting the classes randomly in the piece of paper. Finally, 104 students were selected as the sample of this study. Unfortunately, there were only 95 students who participated.

Two techniques were used to collect the data, that are ready-made questionnaires Reading attitude, which was developed by Tullock, Regina, and Alexander, Estill (1980) which consisted of 25 Likert scale items, and Reading Motivation Questionnaire (MRQ) by Wigfield and Guthrie (1997) which consists 53 Likert-scale items, and Reading Comprehension Test which consists 40 short essay questions. The writer's consideration to use the two questionnaires is because the two questionnaires have been used for research in some schools in Indonesia.

Reading Attitude Questionnaire score is classified into two categories, which are a positive Attitude and Negative
Attitude. To decide students' attitude toward reading, the classification system for reading attitude judgment is classified into two categories, which are negative $(\leq 3.0)$ and positive $(\geq 3.0)$. Each item of the questionnaire has a fivepoint Likert scale, strongly agree (5), agree (4), undecided (3), disagree (2), and strongly disagree (1).

The reading motivation questionnaire was scored by assigning the value of one to four points to the chosen response. A response indicating a low level of motivation receives one point, and those indicating a high level of motivation receive four points. The possible range of scores for the MRQ is 53 for the lowest score and 212 for the highest score. There are three levels of reading motivation, which are high motivation (161-212), medium motivation (107-160), and low motivation (53-106). Before the test was tried out to non-sample, the test was validated by ten experts' judgments in order to rate the level of appropriateness and difficulties of the test. The experts' judgments were chosen from English teachers of SMA Srijaya Negara Palembang and SMA Islam Az-Zahrah Palembang and 5 English Education lecturers of Sriwijaya University. The test was tried out to eleventh graders of SMA Islam Az-Zahrah Palembang, in which participants consisted of 30 students. The writer used Cronbach Alpha SPSS version 25 to investigate the reliability of the reading test. After the test was tried out, the result of the reliability was $(\mathrm{r}=0.75)$, which is higher than 0.70, and the test is considered reliable.

Before doing the reading comprehension test, students were asked to fill the two questionnaires. Once they finished filling the questionnaires, students were not allowed to answer the reading comprehension test before the writer asked. The duration of answering the reading comprehension was given only 60 minutes if some students had not finished answering all the questions; they could not continue answering the test.

\section{RESULTS AND DISCUSSION}

\section{Analysis of Reading Attitude}

Reading the attitude of the students was obtained, and it was found that the mean is 2.95 , and a standard deviation is 0.56 . The writer also reveals that $59 \%$ of students were negative in reading attitude. In comparison, $41 \%$ of students were positive in reading attitude. Table 1

\section{Analysis of Reading Motivation}

It was revealed that the mean reading motivation of students was 2.73 , and a standard deviation of 0.32 , based on the data obtained. It was also shown that $2 \%$ of the students had low motivation in reading comprehension, and $79 \%$ of the students had medium reading comprehension motivation. There were only $19 \%$ of the students were highly motivated. $\underline{\text { Table } 2}$ 
TABLE 1 | Result of Reading Attitude

\begin{tabular}{cccc}
\hline Range of Score & Reading Attitude & N & Total \% \\
& Judgment & & \\
$\geq 3.0$ & Positive Attitude & 39 & $41 \%$ \\
$\leq 3.0$ & Negative Attitude & 56 & $59 \%$ \\
& Total & 95 & $100 \%$ \\
\hline
\end{tabular}

TABLE $2 \mid$ Result of Reading Motivation

\begin{tabular}{cccc}
\hline Range of Score & Reading Motivation & $\mathrm{N}$ & Total \% \\
& Level & 18 & $19 \%$ \\
$161-212$ & High Motivation & 75 & $79 \%$ \\
$107-160$ & Medium Motivation & 2 & $2 \%$ \\
$53-106$ & Low Motivation & 95 & $100 \%$ \\
\hline
\end{tabular}

TABLE 3 | Mean and Standart Deviation of Reading Motivation

\begin{tabular}{ccc}
\hline $\mathrm{N}$ & Mean & Std. Deviation \\
95 & 2.73 & 0.32 \\
\hline
\end{tabular}

\section{Analysis of Reading Comprehension Test}

The mean Reading comprehension achievement test was 67.55 , and a standard deviation was 12.19 . Since score 67 is considered the passing grade level of eleventh graders of SMA Srijaya Negara Palembang, it can be determined that their test was passed if students' reading comprehension achievement level was higher than 67. Meanwhile, for those who got below 67 were considered below the passing grade.

TABLE $4 \mid$ Mean and Standard Deviation of the Reading Comprehension Test

\begin{tabular}{ccc}
\hline $\mathrm{N}$ & Mean & Std. Deviation \\
95 & 67.55 & 12.19 \\
\hline
\end{tabular}

Based on the data below, it can be seen that there were 56 students, or $59 \%$ of students whose scores were $>67$, while 39 students, or $41 \%$ of students whose scores were $<67$. The writer concluded that samples were successful in doing the reading comprehension achievement test, which consisted of 40 items of short essay questions.

TABLE 5 | Result of Reading Comprehension Test

\begin{tabular}{cccc}
\hline $\begin{array}{c}\text { Range of } \\
\text { Score }\end{array}$ & Score Category & N & Total \% \\
$>67$ & Pass the Passing Grade & 56 & $59 \%$ \\
$<67$ & Below the Passing Grade & 39 & $41 \%$ \\
& Total & 95 & $100 \%$ \\
\hline
\end{tabular}

Determine the normality of the test, the writer used the normality test before obtaining the correlation analysis. The result showed that the Reading Attitude, Reading motivation, and Reading Comprehension test revealed to be expected. The significance value of these variables was higher than 0.05 . 
TABLE 6 | One-Sample Kolmogorv-Smirnov Test

\begin{tabular}{ccc}
\hline Variables & Kolmogorv Smirnov Normality & Sig. \\
& Score & \\
Reading Attitude & 0.317 & .074 \\
Reading Motivation & 0.068 & .200 \\
Reading Comprehension & 0.149 & .238 \\
\hline
\end{tabular}

\section{Correlation Analysis}

The writer found out that the r-obtained of reading attitude and reading comprehension achievement was $-.350^{* *}$. The Pearson Correlation number was given a minus (-) symbol, which showed the negative direction. The writer found out the value of r-table to check the value of r-obtained to make sure that there was a significant correlation between the variables. If the value of $r$-obtained is higher than the value of $r$-table and $p$ (probability) is lower than 0.05 , it can be concluded that there is a significant correlation between the variables. It showed that the r-obtained $\left(-.350^{* *}\right)$ was higher than the value of r-table (0.263), and the p-value (0.001) was lower than 0.05 . It showed that reading attitude and reading motivation had a statistically significant correlation. Pearson's correlation coefficient indicates that there was a weak significant correlation between reading attitude and reading comprehension.

TABLE $7 \mid$ Correlation Analysis of Reading Attitude and Reading Comprehension

\begin{tabular}{ccc}
\hline & & Reading Comprehension \\
& Pearson Correlation & -.350 \\
Reading Attitude & Sig. (2-tailed) & .001 \\
& $\mathrm{~N}$ & 95 \\
\hline
\end{tabular}

The Pearson product correlation between reading motivation and the reading comprehension revealed that the Pearson Correlation value was -.295**. It shows that the Pearson Correlation values were higher than the r-table $(0.263)$ and had a significance value, which was not more than 0.05 .
Pearson's correlation coefficient $r$ indicated a weak significant correlation between reading motivation and reading comprehension. It can be concluded that reading motivation and reading comprehension had significant negative and weak correlations.

TABLE 8 |Correlation Analysis of Reading Motivation and Reading Comprehension

\begin{tabular}{ccc}
\hline & & Reading Comprehension \\
& & -.295 \\
Reading Motivation & Sig. (2-tailed) & .004 \\
& $\mathrm{~N}$ & 95 \\
\hline
\end{tabular}

The value of r-obtained Pearson product-moment of reading attitude and reading motivation was 0.106 . Moreover, the significant value ( $\mathrm{p}$-value) was 0.305 . On the contrary, the value of r-obtained is lower than the value of r-table (0.263), and the level of probability is higher than 0.05 . In conclusion, there was no significant correlation between reading motivation and reading attitude, and it had a very weak correlation according to the degree of correlation coefficient from the interpretation.

TABLE 9 | Correlation Analysis of Reading Attitude and Reading Motivation

\begin{tabular}{ccc} 
& & Reading Motivation \\
& Pearson Correlation & .106 \\
Reading Attitude & Sig. (2-tailed) & .350 \\
& N & 95 \\
\hline
\end{tabular}

The result revealed that the correlation coefficient between the predictor variables total and the criterion variable total was .435 with a significance value of .000 . Thus, it can be concluded that there was a significant correlation between predictor variables and the criterion variable. The contribution of predictor variables (Reading Attitude and Reading Motivation) to the criterion variable (Reading Comprehension) was $19 \%$. 
TABLE 10 | Correlation Analysis of Reading Attitude and Reading Motivation

\begin{tabular}{ccccc}
\hline Variables & $\mathrm{R}$ & $\mathrm{R}$ Square & $\mathrm{F}$ & $\mathrm{Sig}$ \\
Predictor variables and the criterion & .43 & & 10.75 & .00 \\
variable & 5 & .190 & 7 & 0 \\
\hline
\end{tabular}

It was shown that there was a strong negative, and weak correlation between the eleventh graders' reading attitude and reading comprehension. Reading motivation and reading comprehension also had significant negative and very weak correlation. Meanwhile, reading attitude and reading motivation revealed no significant correlation and had a very weak correlation.

Findings related to attitude and achievement in this study indicated that having a negative Attitude in reading was not guarantee that students had low achievement in reading comprehension. Still, most students are getting good achievement in reading. Learners who have experience reading English texts tend to have more desire to read English texts than those who do not. It is due to the knowledge of grammars and vocabulary they have. It helps learners to understand more about English materials that can challenge them, such as scientific journals. It can be concluded that learners who fond of reading simple English texts tend to lack reading English reading experience.

\section{DISCUSSION}

According to Pearson-product moment correlation analysis to check whether there were any significant correlations among the three variables. It was found that there was a significant negative correlation between reading attitude and reading comprehension of the eleventh graders. The result of the correlation coefficient shown that there was a negative and weak correlation between the two variables. There was a significant negative correlation between reading motivation and reading comprehension of the eleventh graders. The correlation coefficient showed that there was also a negative and weak correlation between the two variables. The correlation coefficient number was given the minus (-) symbol, which is the correlation direction was negative.

The descriptive statistics of reading the Attitude Questionnaire showed that the eleventh graders were in negative attitude. It can be seen in Table 11; it shows that the positive attitude of reading was $41 \%$, and the negative attitude was $59 \%$. This finding was contrasted with the students' reading comprehension achievement. There were 56 students (59\%) who passed the passing grade (67) and 39 students $(41 \%)$ who did pass the passing grade (67). Also, Therefore, findings related to attitude and achievement in this study indicated that having a negative Attitude in reading was not guarantee that students had low achievement in reading comprehension. Still, most of students getting good achievement in reading.
The descriptive statistics of the Reading Motivation Questionnaire showed that the eleventh graders were in medium motivation. According to the mean score of each MRQ (Motivations of Reading Questionnaire) aspects, the lowest mean score was the Reading Work Avoidance aspect, which consists of four items; (1) I do not like vocabulary questions, (2) Complicated stories are no fun to read, (3) I do not like reading something when the words are too complicated, (4) I do not like it when there are too many people in the story.

Marsela (2017) believes that learners who have more experience in English reading have more desire to read the English texts. They would find it easier to communicate in English texts than those that lack expertise. That is because of their knowledge of grammar and vocabulary than those who have not. This fact helps them understand English content, including some challenging English texts that can challenge them, such as papers. According to the above claims, it can be inferred that learners who prefer to read simple English texts can be defined as learners who lack knowledge in reading English

\section{CONCLUSION}

When students have reading skills and feel comfortable reading, they will have a more positive reading attitude. This condition will support students in improving their reading skills and comprehension. Reading attitude is one aspect of self-perception of reading ability. In this study, students' reading attitude was negative, and their reading motivation was medium, while their reading comprehension achievement passed the passing grade, indicating good. Any causes, such as pressure, may occur. They do not like reading personally; once they were given a reading assignment, they have to do so to get a good score. They can also feel under pressure that they need to finish the reading assignments on time.

Based on the research questions, there were three conclusions drawn in this study. First, the writer revealed that there was a significant correlation between reading attitude and reading comprehension achievement. Second, reading motivation and reading comprehension achievement had a significant correlation. However, reading attitude and reading motivation were revealed that had no significant correlation, and it had a very weak correlation according to the degree of correlation coefficient from the interpretation.

Based on the calculation of the mean of students' reading attitude, students' got a higher level. It means the teacher and parents must be consistent in overseeing the students to 
make this attitude better. The government role to supervise the changes will have a significant impact. Students' negative reading attitude also needs to be solved in order to create an enormous right reading attitude around the students and the better chance, which could influence the other achievement not only in reading. The parents and family can bridge this problem, and they are expected to provide some relevant reading materials in their family. Thus, the children or students will engage, and their good attitude might be applied accordingly, not only in school. Despite the family, the teachers are supposed to cooperate with the librarian and headmaster for supplying relevant books in the school library. Without ignoring the printed reading books, it seems very useful if the online library is also provided using internet connection in school. Thus, the positive attitude in reading based on the technological era may help the students in learning. In addition, the roles from the government need to be elaborated; it will be more beneficial if they always check the supplying books in schools and provide recent books in routine. They can have some training for the teachers and librarians to promote and support the online library or just apply the implementation of using the book properly. Reading comprehension activity should be taken more seriously during the learning process.

The writer expects that other researchers are encouraged to figure out how to further advance the reading comprehension achievement, to find other population which has different characteristics with the population in this study, to find different population which has different characteristics with the population in this study and to use the other recent instruments for measuring the students' reading comprehension test, reading attitude and reading motivation to make some better improvements.

The writer may, after all, draw any recommendations based on the above conclusions. Thus it could address some significant benefits toward many related aspects of education. To motivate and invite the students to read, educators should be extra persuasive. This often requires the parents' guidance, as in the family, the mindset of constructing students' characters towards reading is established dominantly. However, if there is no strong communication between teachers, parents, and the learner, it is difficult to create a festive reading environment.

\section{ACKNOWLEDGEMENTS}

The author would like to express her heartfelt appreciation to her advisors for their profound direction, supportive advice, genuine assistance, great inspiration, and encouragement. The writer also expresses her gratitude to all of the lecturers at the English Education Study Program who had taught her during her study. The writer would also like to add to the Headmasters, English teachers, and eleventh graders of SMA Srijaya Negara Palembang for their assistance and cooperation.

\section{REFERENCES}

Ahmadi, M. R., \& Pourhosein Gilakjani, A. (2012). Reciprocal teaching strategies and their impacts on English reading comprehension. Theory and Practice in Language Studies, 2(10), 2053-2060.

Allan, H. R., \& Smith, N. B. (1990). Reading for today's children. Englewood Cliff, NJ: Prentice-Hall.

Amalia, F., Inderawati, R., Erlina, E. (2018). Reading comprehension achievement on narrative text by using REAP strategy. Channing: Journal of English Language Education and Literature. 3(1). 1-7.

Barbara, A. (2012). Character Building untuk Remaja. Batam: Karisma Publishing Group.

Brummit, J. (2008). What is reading comprehension?. Retrieved from http://k12reader.com/what-is-readingcomprehension/

Cambria, J., \& Guthrie, J. T. (2010). Motivating and engaging students in reading. The NERA Journal, 46(1), 16-29. Retrieved from

http://literacyconnects.org/img/2013/03/motivatingand-engaging-students-in-reading-cambriaguthrie.pdf.

Chun, C. W. (2009). Critical literacy and graphic novels for English-language learners: Teaching literacy: Journal of Adolescent \& Adult Literacy, 53(2), 144153.

Fraenkel, J.R., \& Wallen, N. E. (2012). How to design and evaluate research in education. (8th ed.). Boston: McGraw Hill

Gorard, S., Lee, B. H., \& Davies, P. (2011). Do attitudes and aspirations matter in education?: A review of the research evidence. Saarbrucken: Lambert Academic Publishing.

Guthrie, J. T., Wigfield, A., You, W. (2012). Instructional contexts for engagement and achievement in reading: Handbook of Research on Student Engagement. New York, NY: Longman.

Grabe, W., \& Stoller, F.L. (2001). Reading for academic purpose: Guidelines for ESL/EFL teachers. In: M. Celce-Murcia (Ed.), Teaching English as a second or foreign language (pp. 187-203). Boston: Heincle \& Heincle.

Hamra, A., \&Syatriana, E. (2010). Developing a model of teaching reading comprehension for ESL students. TEFLIN Journal, 21(1), 27-40. DOI: http://dx.doi.org/10.15639/teflinjournal.v21i1/27-40

Heilman, A. W. (2002). Principles and practices of teaching reading. White Plains, NY: Pearson Education.

Li, H., \& Wilhelm, K. H. (2008). Exploring pedagogical reasoning: Reading strategy instruction from two teachers' perspectives. The Reading Matrix, 8(1), 96110.

Marsela, S. (2017). The correlations between reading motivation, and reading comprehension of the eleventh grade students of MAN 2 Palembang. (Unpublished undergraduate thesis). University of Islam Raden Fatah, Palembang. 
Matthewson, G. C. (2004). Model of attitude influence upon reading and learning to read, in R. B. Ruddell\& NJ. Unrau (eds.), Theoretical Models and Processes of Reading. International Reading Association, Newark, DE.

McMillan, J. H., \& Schumacher, S. (2010). Research in education: Evidence-based inquiry ( $7^{\text {th }} \mathrm{ed}$.). Englewood Cliffs, NJ: Pearson Education.

Moriyanti. (2015). The correlation between reading motivation and reading comprehension achievement (a correlational study at SMKN 1 Banda Aceh). Electronic theses and dissertation of Universitas Syiah Kuala.

Rizqiyah, H., Vianty, M., \&Erlina, E. (2016). Improving Functional Reading Achievement of the Eighth Grade Students of SmpNegeri 10 Palembang Through Collaborative Strategic Reading (Csr) (Doctoral Dissertation, Sriwijaya University).

Rojak, A. A. (2018). Exploring students' attitude toward extensive reading (A case study at the tenth grade of SMAN 9 Kota Tangerang Selatan in academic year 2017/2018). Institutional Repository UIN Syarif Hidayatullah Jakarta.

Royer, J. M. (2004). Uses for the sentence verification technique for measuring language comprehension. Amherst, Massachusetts: Reading Success Lab. Retrieved from http://www.readingsuccesslab.com/Reading_Compre hension.html

Taboada, S., \& McElvany, O. (2009). Intrinsic and extrinsic motivation. Retrieved from http://www.excel.org.uk/content/index.php/main/teac hing and learning

Tullock, R., Regina. S. \& Estill, L. (1980). An assessment of University students' attitudes toward Foreign Language

Tunnel, Carder, Justen \& Pahub. (1991). Correlates of reading achievement and attitude: a national assessment study. Journal of education research, 78(5), 159-167.

Walberg, H. J. \& Tsai, S. L. (1995). Correlates of reading achievement and attitude: A national assessment study. Journal of Educational Research, 78(5), 159167.

Wigfield, A. \& Guthrie, J.T. (1997). Relations of children's motivation for reading to the amount and breadth of their reading. Journal of Educational Psychology, 89, 420-432.

Yumei, J. (2009). Motivation and its relationship with reading achievement in an urban middle school. The Journal of Educational Research. 100(4), 81-101
Conflict of Interest Statement: The authors declare that the research was conducted in the absence of any commercial or financial relationships that could be construed as a potential conflict of interest.

Copyright (C) 2021 Tisa, Sofendi and Eryansyah. This is an open-access article distributed under the terms of the Creative Commons Attribution License (CC BY). The use, distribution or reproduction in other forums is permitted, provided the original author(s) and the copyright owner(s) are credited and that the original publication in this journal is cited, in accordance with accepted academic prac- tice. No use, distribution or reproduction is permitted which does not comply with these terms. 
Appendix 1

Nama :

Kelas :

\section{Reading Attitude Questionnaire \\ (Anglet Sikap Dalam Membaca)}

Petunjuk: Pilihlah pernyataan-pernyataan di bawah ini sesuai pendapat anda dan beri satu tanda $(\sqrt{ })$ untuk setiap pertanyaan di kolom $1,2,3$, atau 4 .

Keterangan:

1: Sangat tidak setuju

3: Setuju

2: Tidak Setuju

4: Sangat Setuju

\begin{tabular}{|c|c|c|c|c|c|}
\hline No & $\begin{array}{c}\text { Statements } \\
\text { (Pernyataan) }\end{array}$ & 1 & 2 & 3 & 4 \\
\hline 1. & $\begin{array}{l}\text { You feel you have better things to do than read. } \\
\text { (Anda merasa anda memiliki hal lain yang lebih bermanfaat dari pada membaca) }\end{array}$ & & & & \\
\hline 2. & $\begin{array}{l}\text { You seldom buy a book. } \\
\text { (Anda jarang membeli sebuah buku.) }\end{array}$ & & & & \\
\hline 3. & $\begin{array}{l}\text { You are willing to tell people that you do not like to read. } \\
\text { (Anda bersedia memberitahukan kepada orang-orang kalau anda tidak senang membaca.) }\end{array}$ & & & & \\
\hline 4. & $\begin{array}{l}\text { You have a lot of books in your room at home. } \\
\text { (Anda memiliki banyak buku di kamar anda di rumah.) }\end{array}$ & & & & \\
\hline 5. & $\begin{array}{l}\text { You like to read a book whenever you have free time. } \\
\text { (Anda senang membaca buku saat anda memiliki waktu luang.) }\end{array}$ & & & & \\
\hline 6. & $\begin{array}{l}\text { You get really excited about the book you have read. } \\
\text { (Anda merasa senang jika telah menyelesaikan membaca buku.) }\end{array}$ & & & & \\
\hline 7. & $\begin{array}{l}\text { You love to read. } \\
\text { (Anda Cinta membaca.) }\end{array}$ & & & & \\
\hline 8. & $\begin{array}{l}\text { You like to read books by well-known authors. } \\
\text { (Anda senang membaca buku dari pengarang terkenal.) }\end{array}$ & & & & \\
\hline 9. & $\begin{array}{l}\text { You never check out a book from the library. } \\
\text { (Anda tidak pernah meminjam buku dari perpustakaan.) }\end{array}$ & & & & \\
\hline 10. & $\begin{array}{l}\text { You like to stay at home and read books. } \\
\text { (Anda senang berada di rumah dan membaca buku.) }\end{array}$ & & & & \\
\hline 11. & $\begin{array}{l}\text { You seldom read except when you have to do a book report. } \\
\text { (Anda jarang membaca kecuali anda harus membuat laporan tentang sebuah buku.) }\end{array}$ & & & & \\
\hline 12. & $\begin{array}{l}\text { You think reading is a waste of time. } \\
\text { (Anda berpikiran bahwa membaca hanya membuang-buang waktu.) }\end{array}$ & & & & \\
\hline 13. & $\begin{array}{l}\text { You think reading is boring. } \\
\text { (Anda berpikiran bahwa membaca adalah hal yang membosankan.) }\end{array}$ & & & & \\
\hline 14. & $\begin{array}{l}\text { You think people are strange when they read a lot. } \\
\text { (Anda berpikiran bahwa orang-orang yang banyak membaca adalah aneh.) }\end{array}$ & & & & \\
\hline 15. & $\begin{array}{l}\text { You like to read to escape from the problem. } \\
\text { (Anda senang membaca untuk menghindari masalah.) }\end{array}$ & & & & \\
\hline 16. & $\begin{array}{l}\text { You make fun of people who read a lot. } \\
\text { (Anda menertawakan orang-orang yang banyak membaca.) }\end{array}$ & & & & \\
\hline 17. & $\begin{array}{l}\text { You like to share books with your friends. } \\
\text { (Anda senang untuk saling meminjam buku dengan teman anda.) }\end{array}$ & & & & \\
\hline 18. & $\begin{array}{l}\text { You would rather someone just tell you information so you won't have to read to get it. } \\
\text { (Anda lebih senang jika seseorang menceritakan langsung sebuah informasi sehingga anda tidak perlu } \\
\text { membaca untuk mendapatkannya.) }\end{array}$ & & & & \\
\hline 19. & $\begin{array}{l}\text { You hate reading. } \\
\text { (Anda tidak suka membaca.) }\end{array}$ & & & & \\
\hline 20. & $\begin{array}{l}\text { You generally check out a book when you go to the library. } \\
\text { (Pada umumnya anda meminjam buku kalau anda berkunjung ke perpustakaan.) }\end{array}$ & & & & \\
\hline 21. & $\begin{array}{l}\text { It takes you a long time to read a book. } \\
\text { (Butuh waktu yang lama bagi anda untuk membaca sebuah buku.) }\end{array}$ & & & & \\
\hline 22. & You like to broaden your interests through reading. & & & & \\
\hline
\end{tabular}




\begin{tabular}{|c|c|c|c|c|c|}
\hline No & $\begin{array}{l}\text { Statements } \\
\text { (Pernyataan) }\end{array}$ & 1 & 2 & 3 & 4 \\
\hline & (Anda senang memperluas wawasan pengetahuan anda melalui membaca.) & & & & \\
\hline 23. & $\begin{array}{l}\text { You read a lot. } \\
\text { (Anda banyak sekali membaca.) }\end{array}$ & & & & \\
\hline 24. & $\begin{array}{l}\text { You like to improve your vocabulary so you can use more words. } \\
\text { (Anda senang untuk menambah kosa kata anda sehingga anda bisa menggunakan lebih banyak kata-kata.) }\end{array}$ & & & & \\
\hline 25. & $\begin{array}{l}\text { You like to get books for gifts. } \\
\text { (Anda senang menerima buku sebagai hadiah.) }\end{array}$ & & & & \\
\hline
\end{tabular}

\section{Terima Kasih}

